\title{
Investigating the Influence of Topic Writing in Biology Teaching on Students' Critical Thinking Disposition Improvement
}

\author{
Mingxing Chen, Nongnong Shi* \\ School of Life and Environmental Sciences, Hangzhou Normal University, Hangzhou, China
}

Email address:

867594089@qq.com (Nongnong Shi)

${ }^{*}$ Corresponding author

To cite this article:

Mingxing Chen, Nongnong Shi. Investigating the Influence of Topic Writing in Biology Teaching on Students' Critical Thinking Disposition Improvement. Science Journal of Education. Vol. 4, No. 6, 2016, pp. 206-213. doi: 10.11648/j.sjedu.20160406.17

Received: November 30, 2016; Accepted: December 9, 2016; Published: January 6, 2017

\begin{abstract}
The California Critical Thinking Disposition Inventory-Chinese Version (CTDI-CV) revised by Ms Meici Peng et al. were used to sample and analyze the students from a high school in Hangzhou, China. The average score of the students' critical thinking disposition was 255.9 , and no single dimension exceeded 40 points, suggesting that the overall critical thinking was weak. The students' score of critical thinking slightly increased from grade one to grade three, but the increase was very subtle, which was similar to the findings from other studies. The reasons were analyzed from three aspects: social and cultural background, family education, and school education system. Two classes in grade one were chosen to perform the parallel practical study for two months. These two classes had no significant difference in CTDI-CV pre-test. For the experimental class, we conducted teaching experiment for two months, assigning several biology topic writings related to class knowledge; the teachers graded the assays and gave feedback. The control class was given normal teaching. The experimental class showed extremely significant improvements in truth seeking $(p=0.006<0.01)$ and analytical ability $(p=0.003<0.01)$, indicating that topic writing could help improve the critical thinking ability of high school students in certain aspects, although it didn't get significantly increased total score $(p=0.059>0.05)$ of critical thinking disposition compared to the pre-test. Some feasible suggestions on how to train the critical thinking ability of students in biology teaching were also proposed.
\end{abstract}

Keywords: Critical Thinking, Biology Topic Writing, CTDI-CV Analysis

\section{Introduction}

The concept of 'critical thinking' originated from the famous American educator John Dewey (1859-1952) who proposed 'reflective thinking', which points out that for all the knowledge, belief and information, people should fully considerate the reasons and evidence that support them, as well as the conclusions they can draw from them, and keep active, continuous and careful thinking [1]. In the 1940s, with the development of psychology and pedagogy, the relationship between critical thinking and education has drawn more attention. In the 1970 s, the critical thinking movement was initiated in United States. And in the 1980s, with the critical thinking research getting deeper, the system and curriculum about critical thinking education started to emerge [2]. In 1996, the United States issued the 'National Science Education
Standards', which states that 'the focus of school education is to help students master a variety of skills that are used daily, including critical thinking, creative problem-solving skills and team work spirit [3]. So far, many high schools and colleges in western societies have set up courses and institutions for critical thinking. The two books 'critical thinking: take you out of the erroneous zone of thoughts' and 'learn to ask questions: guide for critical thinking', which have been translated to Chinese, are two of the excellent teaching books. Therefore, we can see that critical thinking education has gradually become the mainstream of education in western countries since the twentieth century, and also drawn attentions from the Chinese educators. In 2003, China conducted the eighth new curriculum reform. The new curriculum based on the idea of 'promoting the development of each student', put the teaching focus on highlighting the 
subjectivity and initiative of students, and promoted the implementation of quality-oriented education, aiming to help students achieve integrated development and obtain independent personality [4]. In the background of the new curriculum reform, the new curriculum standards also made clear requirements for the critical thinking training. For example, in the curriculum objectives of 'High School Biology Curriculum Standard (Experiment)', critical thinking was listed as one of the goals for cultivating scientific thinking [5]; and the high school literature and English curriculum standards also made the similar requirements. The reasons for focusing on critical thinking training are consistent with the progress of social development and educational philosophy.

Nowadays, people think critical thinking is about frequent reflection, careful judgment, and active exploration; it is a kind of free thinking, neither sticking to conventions nor being blindly confident, but soaring in the law of rationality to seek the truth. The characteristics of critical thinking are not rigidly adhering to old knowledge or traditions, but boldly challenging, carefully verifying, bravely exploring, and ultimately reaching the truth. Under the current social background of complicated and enormous amount of information, and under the goal of cultivating innovative talents, the critical thinking training meets the needs of students to survive and improve in the information age, and to develop and utilize their creativity; it also meets the need of forming the educational concept of humanism and constructivism. Therefore, the cultivation of critical thinking is a critical part of the current education system. It is very important to understand the current situation and characteristics of the critical thinking ability of high school students, and to think about how to train students' critical thinking in the teaching process.

In education field, there are several effective ways to cultivate students' critical thinking, such as logical learning, observation of problem-solving process, reading and writing practice, and small group discussion. Among them, practice of writing small articles is relatively easier to conduct in anpractical research, and also doesn't affect the course hour and progress. The life related cases and problems can easily resonate with the students and inspire them to pay more attention to things around, cultivating their habit of careful thinking and judging.

In this study, we randomly sampled and analyzed the students from a high school in Hangzhou, China by using the CTDI-CV amended by Meici Peng et al. [6], and examined the data from seven aspects: truth seeking, open mind, analytical ability, systematizing ability, confidence of critical thinking, curiosity, and cognitive maturity. Through this study, we aimed to understand the current situation of high school students' critical thinking ability and analyze the reasons. By conducting the practical research about topic writing for biological problems, we tried to find effective ways to cultivate and improve the critical thinking disposition of high school students, and then propose practical suggestions that might be helpful for the relevant educational institutions.

\section{Study Process and Methods}

\subsection{Study Subjects}

100 students were randomly selected from the first, second and third grade from a high school in Hangzhou, China, with a total of 300 students.

\subsection{Study Tools}

\subsubsection{Questionnaire and Analysis}

We conducted the survey by using the California Critical Thinking Disposition Inventory - Chinese Version (CTDI-CV), which was revised by Meici Peng et al. and passed the local reliability and validity test. This inventory includes seven dimensions and seventy items: truth seeking (10 items), open mind (10 items), analytical ability (10 items), systematizing ability (10 items), confidence of critical thinking (10 items), curiosity (10 items) and cognitive maturity (10 items). Each item has six options in a six-level format: the forward questions have 6 levels, which are strongly agree, quite agree, moderately agree, slightly agree, quite disagree, strongly disagree, with the corresponding score from 1 to 6 ; the reverse questions are in turn corresponding to score from 6 to 1 . According to the denotation of the total score provided by the table: if the total score $\leqq 210$, the overall critical thinking disposition is negative; if the total score ranges from 210 to 280 , the overall disposition is relatively weak; if the total score $\geqq 280$, the overall disposition is relatively ideal; if the total score $\geqq 350$, the overall disposition is very strong. For single dimension, if the score $\leqq 30$, then the subject's critical thinking disposition in this dimension is negative; if the score ranges from 30 to 40 , then the critical thinking disposition in this dimension is neutral; if the score $\geqq 40$, the disposition in this dimension is relatively ideal; if the score $\geqq 50$, the disposition in this dimension is very strong.

According to the detailed scores of students' critical thinking in seven dimensions, we conducted analysis and found the current situation of high school students' critical thinking disposition. We also analyzed the reasons from the aspects of culture, family education and school education system.

\subsubsection{Practical Study}

Pre-test survey: Two classes in grade 1 were randomly chosen and divided into experimental and control class individually, using CTDI-CV on them for the pre-test. SPSS19.0 software was applied to analyze their scores. Thepractical study was carried out as follow:

I. Experimental class based on the biology knowledge in their text book, references and real life, three problem-based topic writing projects were assigned to the students in each month, requiring students to write short articles with approx. 500 words. The teachers would grade the articles, and mark the obvious logical errors if there's any.

II. Control class: no topic writing assignment, just maintain the normal teaching.

III. The experiment lasted for two months.

IV. By the end of the experiment, CTDI-CV was used to 
post-test the students' critical thinking disposition. SPSS 19.0 was applied to analyze the data.

\section{Results and Analysis}

\subsection{Questionnaire}

A total of 300 copies of CTDI-CV sheets were sent out to students in grade 1, 2, 3 from a high school in Hangzhou, and 294 of them were collected. The collection rate was $98 \%$. After screening, 287 of them were valid, and the valid rate was 97.6\%. The results are shown in Table 1 .

Table 1. The average CTDI-CV score of the students in each grade.

\begin{tabular}{lllll}
\hline Dimensions & Grade1 & Grade2 & Grade3 & $\begin{array}{l}\text { Average } \\
\text { score }\end{array}$ \\
\hline Truth seeking & 37.60 & 37.50 & 38.30 & 37.80 \\
Open mind & 36.6 & 37.50 & 37.90 & 37.30 \\
Analytical ability & 35.20 & 35.70 & 38.10 & 36.50 \\
Systematizing ability & 34.90 & 35.10 & 37.70 & 36.00 \\
Confidence of critical thinking & 35.90 & 36.30 & 37.90 & 36.70 \\
Curiosity & 33.20 & 36.10 & 34.40 & 34.20 \\
Cognitive maturity & 36.20 & 37.10 & 38.40 & 37.40 \\
Total score & 249.60 & 255.30 & 262.70 & 255.90 \\
\hline
\end{tabular}

The average total score of the students is 255.90 , between 210 and 280, indicating that the overall critical thinking disposition is relatively weak. For the single dimension, none of them is above 40, suggesting that the disposition in all seven dimensions is relatively weak. This result is consistent with the findings from other scientists in China, e.g. Shijian Wang (2014) did the critical thinking survey on grade 1 students from a high school and showed that the average score was 249.5, and none of the single dimension score was above 40 [7]. Huiyun Gong (2009) also did the survey and found that the average score of the grade 2 students in a high school was 267 , which was slightly higher than our result, but was still less than 280[8]. Guangpu Ouyang (2012) did the critical thinking disposition survey on the students from a ' 985 ', university, and found that the average score of undergraduate students was 278.8, still less than 280 [9]. Therefore, the critical thinking disposition of China's high school students is relatively weak. In terms of the differences among grades, the students' critical thinking score tends to increase with the grade increases, which is similar to the findings in Taiwan schools, but the increase is small, only about $5.24 \%$.

After specifically analyzing the score of each dimension, we found that the score of curiosity was the lowest, and within this dimension, the item "most of the courses in school are boring" had the lowest score of only 3.12, for which the grade 3 was even lower than grade 2. This indicated that China's education reform still has a long way to go, and the exam-oriented education still has strong negative impact on the curiosity of senior high school students. Critical thinking is a positive, rationality-directed free thinking, which needs more attractive and instructive curriculum. Also, high school students are still in the critical period of forming mature thinking, thereby the correct guidance and cultivation of the concept about life and values are very necessary. In addition, the high school students were also weak in the analytical ability and systematizing thinking, suggesting that the school should put more effort to let the students to think about, analyze and explain problems with the teachers' guide and help. We investigated the reasons for the weak critical thinking disposition of Chinese students from the following aspects:

\subsubsection{Cultural Background}

It is difficult to give a clear definition to 'culture'. One viewpoint is that culture is the behavioral habits and concept of values participated after the long history. The impact of culture on people is enormous, affecting all aspects of life and people's way of thinking. Since the last contrary, China had been struggling to explore the way out for their culture. From The Reform Movement of 1898 to 'Xinhai' Revolution, from Central Plains War to Anti-Japanese War, from War of Liberation to Chinese economic reform, people found that there was only one direction, which was to abandon the constraints of traditional culture and establish a democratic, prosperous and independent China. Until now, the country has finally come out of the decline and turbulence, and stands out among all the countries with the achievements such as the world's $2^{\text {nd }}$ economic entity, the permanent member of United Nations, and the host country of 2008 Olympic Games. Then we started to realize that we need some 'Chinese characteristics', since China is one of the four ancient civilizations, and our ancestors have created many miracles. Therefore we started to pay attention to traditional culture again. Some primary schools set up courses about classical culture, CCTV opened the program about Chinese idioms and riddles, and many traditional activities were held in the public. There's a saying from '1984' written by George Orwell: 'Whoever controlled the past would have the future, whoever dominated the current would govern the past' $[10]$. So then what is our cultural status now? How does it affect our way of thinking?

First of all, the Confucian culture, which had a profound impact on us, has been widely discussed. The concept of honor and disgrace and the respect for authority were frequently mentioned. But these two factors have played a negative role for free questioning and truth seeking. The ancient people paid attention to the moral cultivation and natural harmony; for the contradictions happened in daily life and self-reflections, they used their own intuition and speculation to review and correct the ethics and etiquette, and extracted the long-lasting moral norms and etiquette standards. As scholar Xiaotong Fei written in his 'Native China': "The ancient China was a stable society without frequent changes; the people lived in it could deal with anything with the experiences from the elders, and those who ignored the experiences would suffer [11]. The everlasting moral norms and etiquette were handed down from generation to generation in a slow-paced society, together with the idea of respecting the elders. With the rapid social development, the elders' suggestions are gradually becoming less unshakable, but the intuitive sentimental thinking and the habit of moral criticizing are retained. However, without the 
elders' criticism and the advice from past sages, this kind of criticism is always decorated with nobility and freedom, being used to criticize other people instead of themselves, while the self-reflection and self-cultivation are often overlooked.

Secondly, what is the impact of foreign culture on people? The three key words, 'science', 'democracy', and 'economy', are interdependent and mutually promoting each other, creating the current world together. Science creates more material and technological achievements through the understanding and developing of the nature; economy makes the ideal resource allocation; democracy transfers the social decision-making from dictatorship to the public. However, none of the modes is absolutely correct without flaw. Modernization is renovating the world with each passing day while also bringing many problems, such as environmental pollutions, ecological imbalance, the gap between the rich and the poor, etc. The diversification of society also generates many complicated new problems, which need the talented people in every field to explore the solutions. The global developments of economy and science require us to have the sense of ownership, to actively reflect on the problems of social development, and to protect the earth and the future! This requires people to use critical thinking to understand, analyze and solve all kinds of important problems.

\subsubsection{Family Education}

Family plays an important role on a person's development. The influence is leavening, which will certainly affect the student's way of thinking. Chinese people usually have strong family concepts, and the children are quite dependent on family and parents before entering adulthood or even before going to work. So in China's parent-child relationship, the parents' giving and expectations will inevitably lead to pressures on children, both psychologically and behaviorally; and the children's dependency will also make the family relationship toward the direction of dictatorship. In addition, the centralization of resourses in economy and society, the expanding gap between the rich and the poor, the acceleration of urbanization, the increased pace of life, and the growing living pressure, have made people put more energy and time into work, and thereby some phenomena showed up, such as left-behind children, or grandparents helping to take care of the grandchildren, while the old people tend to spoil and indulge the children. Among the three major family education modes, democratic, autocratic, and laissez-faire [12], the autocratic and laissez-faire modes, which are less reasonable, are more likely to be found in Chinese families. But the democratic family environment is very critical for the children's critical thinking development.

\subsubsection{School Education System}

China's education system is generally more focused on exams and knowledge transfer. The education reform is hoping to reduce the burden on students and achieve quality-oriented education, so that the students will not only learn knowledge, but also learn how to study and how to think, and eventually realize the goals of lifelong learning and happy learning. So far, the reform already has some effects, but the weaknesses of focusing on knowledge transfer and exams are still there. One important reason is that China's education has been faced with the problems of insufficient educational resource and its uneven distribution. People are very sensitive about the issue of education equality. It is not easy to find an educational system that can both consider the resource equality and the fully development of students' individuality. Schools should strengthen the cultivation of critical thinking, which can help students to get out of the thought erroneous zone, eliminate the interference and think freely; critical thinking can also help students to escape the narrow and partial thinking mode, learn to analyze problems comprehensively, improve the accuracy of their judgment, and ultimately be able to affect the social development.

\subsection{Practical Results and Analysis}

In order to ensure that the research conditions are consistent, the influencing factor is unique, and the results are reliable, it is necessary to compare the critical thinking disposition between experimental class and control class before starting the experiment, in order to conduct the practical research with no previous significant differences. Tables 2 and 3 show the CTDI-CV total scores of the two classes in pre-test, as well as the difference analysis:

Table 2. The CTDI-CV total scores of the experimental class and control class (pre-test).

\begin{tabular}{lllll}
\hline Sample & Number & $\begin{array}{l}\text { Average } \\
\text { score }\end{array}$ & $\begin{array}{l}\text { Standard } \\
\text { deviation }\end{array}$ & $\begin{array}{l}\text { Standard } \\
\text { error }\end{array}$ \\
\hline Experimental class & 35 & 250.3429 & 14.52167 & 2.45461 \\
Control class & 38 & 247.4737 & 15.86214 & 2.57318 \\
\hline
\end{tabular}

Table 3. The difference analysis of two classes (pre-test).

\begin{tabular}{lllll}
\hline Levene test for variance equation & t-test for mean equation & & & \\
\hline FP & Mean difference & Standard error difference & t & df \\
\hline 0.81000 .7760 & -2.8692 & 3.5693 & -.8040 & 71 \\
\hline
\end{tabular}

Table 2 shows that the experimental class has 35 students, and the control class has 38 students; their average total scores for CTDI-CV pre-test were 250.34 and 247.47, respectively, which were lower than 280 and higher than 210 , meaning that their critical thinking disposition were both relatively weak, and consistent with the overall situation of the school. Table 3 shows that the results of Levene homogeneity test of variance are $\mathrm{F}=0.081, \mathrm{P}=0.7760>>0.05$, demonstrating that the two classes' variances were equal, no need for correction. The results of t-test are $\mathrm{t}=-0.804, \mathrm{df}=71, \mathrm{P}=0.4240>0.05$, indicating that the critical thinking disposition levels of the experimental class and control class were similar, with no significant difference in the pre-test. Therefore, the prerequisites for using these two classes to do the follow-up 
experiments were met.

\subsubsection{Global Analysis}

The design and purpose of the topic questions assigned to experimental class are shown in Table 4:

Table 4. The design and purpose of the questions for topic writing assignment.

\begin{tabular}{|c|c|c|}
\hline $\begin{array}{l}\text { The corresponding } \\
\text { Knowledge in the } \\
\text { textbooks }\end{array}$ & Questions & Design purpose \\
\hline $\begin{array}{l}\text { Water and inorganic } \\
\text { matter }\end{array}$ & $\begin{array}{l}\text { Japan: In March 2011, affected by the earthquake, the nuclear } \\
\text { leak accident happened in Japanese Fukushima nuclear power } \\
\text { plant. } \\
\text { China: After the nuclear leak occurred in Japan, people in many } \\
\text { cities of China started to buy sea salt insanely since March } 16 \text {, } \\
\text { worrying about that the nuclear leak would contaminate } \\
\text { seawater; some cities even ran out of stock. } \\
\text { Could you explain why this happened? If you run into this, what } \\
\text { would you do? }\end{array}$ & $\begin{array}{l}\text { Let the students learn rational analysis and proper questioning } \\
\text { through reviewing and reflecting on the irrational and } \\
\text { pseudo-scientific events; and also let the students solve the } \\
\text { problems and improve their experience in face of such incidents. }\end{array}$ \\
\hline Bio-macromolecule & $\begin{array}{l}\text { Have you ever seen the advertisement of 'Jinlongyu 1:1:1 blend } \\
\text { oil' (you can find it online)? Which ad are the most familiar to } \\
\text { you? What information does it tell you about the product? Is it } \\
\text { true? Can you talk about your opinion about TV commercial? }\end{array}$ & $\begin{array}{l}\text { The common ad in our daily life has great influence on students. } \\
\text { This question is to let students analyze the purpose of the ad, and } \\
\text { cultivate their pursue about the goods authenticity. These are also } \\
\text { good ways for them to rethink, question and explore the life } \\
\text { events. }\end{array}$ \\
\hline Viruses & $\begin{array}{l}\text { The avian influenza virus is highly specific to certain species, } \\
\text { but in rare cases, it can infect people across species. In 1997, the } \\
\text { first case of human getting infected with avian influenza virus } \\
\text { was found in Hong Kong. By March, 2013, } 3 \text { cases of human } \\
\text { infection with H7N9 avian influenza were found in Shanghai } \\
\text { and Anhui, among which two people died, causing great } \\
\text { anxiety [13]. Do you think we will face an unexpected threat } \\
\text { from a virus in the future? If not, explain why? If yes, what } \\
\text { should you do as a citizen? }\end{array}$ & $\begin{array}{l}\text { Associate the knowledge from textbooks with the social health } \\
\text { problems such as virus invasion. Students cannot fully answer the } \\
\text { question only with the knowledge within textbooks, they need to } \\
\text { search it online. Therefore, it can train the students' ability to } \\
\text { collect information and analyze problems. At the same time, it } \\
\text { asks students to analyze the correct thing to do in times of crisis. } \\
\text { In the absence of experience, this is a good practice for students to } \\
\text { summarize the information and analyze the problems. }\end{array}$ \\
\hline Cell & $\begin{array}{l}\text { Cancer is the number one health threat to human being. What } \\
\text { factors or things in you and your family's daily life that can } \\
\text { cause cancer? The cancer patients in advanced stage suffer a lot. } \\
\text { Please talk about your opinion about hospice care and } \\
\text { euthanasia for the patients in last stage. }\end{array}$ & $\begin{array}{l}\text { This question is connected with students' life, asking students to } \\
\text { examine whether there is risk associated with their lives? At the } \\
\text { same time, students learn how to care for other people through } \\
\text { this question. And the discussion about controversial social issues } \\
\text { euthanasia and hospice care is a good exercise for students' civic } \\
\text { awareness and dealing with "dilemma" problems. }\end{array}$ \\
\hline Respiration & $\begin{array}{l}\text { Respiration gives people the energy to live but now the haze of } \\
\text { our city gives us a lot pain. Except for the ridicule like 'insist } \\
\text { without breathing', what harm do you know about haze? What } \\
\text { can you do to protect yourself, your family, and other people? }\end{array}$ & $\begin{array}{l}\text { Haze is another health killer in our lives, and the situation will } \\
\text { take time to get better. This question asks students to reflect on } \\
\text { their carelessness about this issue, and think about how to protect } \\
\text { themselves and others. This requires collecting, analyzing and } \\
\text { making use of the information, which can guide students to } \\
\text { become a rational and healthy person with a sense of health care. }\end{array}$ \\
\hline Photosynthesis & $\begin{array}{l}\text { Global warming is threatening the security of the world. What } \\
\text { do you do in your daily life to help with the problem? And what } \\
\text { is accelerating the crisis? }\end{array}$ & $\begin{array}{l}\text { The design of this question is similar to the above one. These } \\
\text { issues pay attention to the student's daily life, asking students to } \\
\text { rethink and explore the problems and fallacies in life; these are } \\
\text { also social issues, intending to cultivate students' sense of } \\
\text { ownership and civic awareness. }\end{array}$ \\
\hline
\end{tabular}

After two months of training and coaching on topic writing about the above six biology questions, CTDI-CV was used to re-examine the critical thinking status of the experimental and control classes. Then we found that:

\section{The Overall Levels of Critical Thinking Disposition in the Experimental Class and Control Class, and the Difference Analysis}

Table 5. The overall level of critical thinking disposition in experimental class and control class (post-test).

\begin{tabular}{llll}
\hline Sample & Number & Average score & Standard deviation \\
\hline Experimental class & 35 & 254.2571 & 14.1989 \\
Control class & 38 & 249.5789 & 12.8560 \\
\hline
\end{tabular}

Table 6. Difference comparison of critical thinking disposition between experimental class and control class (post-test).

\begin{tabular}{lllllll}
\hline Levene test for variance equation & t-test for mean equation & & & \\
\hline FP & & Mean difference & Standard error difference & $\mathbf{t}$ & $\mathbf{d f}$ & $\mathbf{P}$ \\
\hline 0.7910 & 0.3770 & 4.6782 & 3.1665 & 1.4770 & 71 & 0.1440 \\
\hline
\end{tabular}


Table 5, 6 show the Levene variance homogeneity test for the two classes in post-test is $\mathrm{F}=0.7910, \mathrm{P}=0.3770>>0.05$, so the variances of the two classes are equal, no need to correct. For the t-test, $\mathrm{T}=-1398$., $\mathrm{Df}=71, \mathrm{P}=0.1440>0.05$, indicating that after the two-month topic writing training, the experimental class had no significant difference in the overall level of critical thinking compared to control class.

\section{The Difference Test for the Experimental Class Between Pre-test and Post-Test}

Table 7. T-test results for the experimental class between pre-test and post-test.

\begin{tabular}{|c|c|c|c|c|c|}
\hline \multicolumn{6}{|c|}{ t-test for mean equation } \\
\hline Mean difference & Standard deviation & Standard error & $\mathbf{t}$ & df & $\mathbf{P}$ \\
\hline 3.9142 & 11.8505 & 2.0031 & 1.9540 & 34 & 0.059 \\
\hline
\end{tabular}

Table 7 shows the difference in the total score of critical thinking disposition before and after the training in experimental class, where $\mathrm{t}=1.9540, \mathrm{df}=34, \mathrm{P}=0.059>0.05$. The average total score is 250.3429 for pre-test and 254.2571 for post-test, which increased after the topic writing training, and is very close to significant level.

After the two-months teaching experiment, the overall improvement of students' critical thinking is not very obvious, probably due to insufficient experimental time. Thinking training is a long process, but our experiment was slightly rushed. However, $\mathrm{P}=0.059$ was quite close to the significance standard 0.05. With longer-lasting experimental period and more topics to write, we think it will be effective. The difference between pre-test and post-test for control class is smaller, and the t-test $P$ value was $0.406>0.05$, not significant (data not shown).

\subsubsection{Single Dimension Analysis}

We compare the differences in the seven dimensions of the experimental class in pre-test and post-test.

Table 8. Differences between pre- and post-test scores in the seven dimensions of the experimental class (35 students).

\begin{tabular}{|c|c|c|c|c|c|c|c|c|}
\hline Dimension & Pre-test & Post-test & Mean difference & Standard deviation & Standard error & coefficient & t & $\mathbf{P}$ \\
\hline Truth seeking & 37.31 & 40.43 & 3.11 & 6.23 & 1.05 & 0.39 & 2.96 & 0.006 \\
\hline Open mind & 34.51 & 36.14 & 1.63 & 6.01 & 1.02 & 0.43 & 1.60 & 0.12 \\
\hline Analytical ability & 35.37 & 38.43 & 3.06 & 5.70 & 0.96 & 0.59 & 3.17 & 0.003 \\
\hline Systematizing ability & 35.06 & 35.66 & 0.60 & 5.34 & 0.90 & 0.51 & 0.66 & 0.51 \\
\hline Confidence of critical thinking & 36.54 & 37.29 & 0.74 & 5.20 & 0.88 & 0.63 & 0.85 & 0.40 \\
\hline Curiosity & 32.54 & 34.09 & 1.54 & 5.00 & 0.85 & 0.46 & 1.83 & 0.077 \\
\hline Cognitive maturity & 36.71 & 35.77 & 0.94 & 4.60 & 0.78 & 0.67 & 1.21 & 0.23 \\
\hline
\end{tabular}

After using t-test to analyze the differences between preand post-test in the seven dimensions for experimental class, we found that after two months of biology topic writing training, the critical thinking disposition of the students had significant improvement in truth seeking and analytical ability dimensions. The differences were both above 3 , and the $\mathrm{P}$ values were 0.006 and 0.003 , respectively, lower than $0.01(<<$ 0.01 ). Especially in the truth seeking dimension, students' score was more than 40 after the writing training, indicating that the students' critical thinking in this aspect had reached a relatively ideal level after two months of training. The other five dimensions did not show significant difference after the training. The total score differences were between 0.60 and 1.65 , but the increase in curiosity dimension was close to significant level, where $\mathrm{P}=0.077$.

The differences in seven dimensions of control class did not show significance (data not shown).

\section{Discussion and Suggestions}

After two months of biology topic writing training, the total score of students' critical thinking disposition increased by 3.9 points. The $\mathrm{P}$ value from t-test was $0.059>0.05$, which was close to but didn't reach the significant level. However, among the seven dimensions, truth seeking and analytical ability both showed significant improvements. Since there were no significant differences in all dimensions for control class, it suggests that conventional teaching cannot improve students' critical thinking disposition within short period, but topic writing training can improve it to a certain extent, especially in the dimensions of truth seeking and analytical ability. Thereby this method is worth trying in high school education.

In the process of question design, we should pay attention to cultivating students to question and inquiry the problems and events in daily life, for example, question 2 guides students to reflect on and explore the ad content, helping students to understand the importance of distinguishing the truth and avoiding being misled, and it also asks students to pay attention to the problems about life and health, activating their desire to explore the surrounding events. Secondly, we should pay attention to students' emotion. The concern about family and society can give students more critical thinking. Moreover, the process of searching for literature, writing and expounding is also a process of reviewing and criticizing on their own thinking. This process is very helpful in improving students' ability to analyze problems and forming the pragmatic attitude. Finally, teachers' comments with no influencing concepts are good for students to reflect on and examine their own thinking.

The results showed that in biology teaching, the biology 
topic writing training helped students to improve their critical thinking disposition, especially in dimensions of truth seeking and analytical ability. Topic writing can lead students to think, analyze and pay attention to people and things around, bringing good motive for students to seek truth and analyze problems. The purposes of the questions were effective, which are closely related to the key concepts of constructivism, humanism and other educational thoughts.

Many biology teaching and literature in critical thinking think open question test is an important way to develop students' critical thinking disposition, because the answers to many open questions are not only one or fixed, but vague, uncertain or controversial. Many scholars hope to let students understand, through these questions, that many problems in life need careful thinking and analysis to get to answer. This kind of training can help students to reflect on their own behaviors, to be more cautious when thinking problems and making decisions, which can improve the critical thinking ability. In addition, except for this, we think the three following aspects are where we need to put more effort in biology teaching, in order to develop students' critical thinking:

\subsection{Classroom Teaching}

Classroom is the main place for the students to absorb knowledge, train their abilities, and cultivate their attitudes and values. The class organization and teaching methods have great impacts on students' learning effect. Then what kind of classroom teaching mode is helpful to cultivating students' critical thinking disposition? We think: 1. discussion or debate can activate students' thinking and interest, clarification and communication about the questions is good for students to reflect on and practice their own thinking. In this process, teachers cannot focus on winning or losing, right or wrong; they should create a harmonious and democratic environment, and pay attention to the brilliant discussion. 2 . The history of science teaching. The history of biological sciences development is a process of scientists breaking through limitations, overcoming difficulties, and making innovations. Their wisdom and perseverance is good material to cultivate students' critical thinking. However, many stories about history of science are far away from us, thus students are hard to resonate with them. Therefore, the teachers need to create an inquiry situation, and make guiding description, in order to inspire students to think and ask questions, and understand the process of finding the truth and the persistence in scientific research.

\subsection{Homework and Test}

Homework and test are the routine methods to consolidate and check the knowledge and skills that the students learn on class. It is an effective supplement to classroom teaching. In order to cultivate the students' critical thinking, we think that the homework and test should connect to students' real life, inspire students' enthusiasm to actively explore, think, and learn, and pay attention to cultivating the ability of logical reasoning.

\subsection{Experiment Teaching and Extracurricular Activities}

Experiment class is where students can verify and explore biological knowledge and laws by themselves. Unlike the fixed knowledge in textbooks, experimental results may be varied due to the subtle changes in conditions. Students can practice their own ability and intention of questioning and exploration by analyzing and rethinking the experimental process and results. The teachers should guide students to learn how to think, explore and discuss, as well as the spirit of cooperation. Biology is closely related to life, many problems in life are associated with biology, such as gender issues, food safety, etc. For extracurricular activities, teachers should properly guide students to pay attention to social events, and carry out discussion and debate about the popular social issues, or organize research activities, etc. [14].

\section{Conclusion}

The overall critical thinking disposition is weak in high school of China although the average score from CTDI-CV test was relatively improved with the increase of their grade, which was similar to the findings from other studies. Two months' practical experiment through six biological topic writings among grade 1 high school students showed extremely significant improvement in two single dimensions of truth seeking $(\mathrm{p}=0.006<0.01)$ and analytical ability $(\mathrm{p}=$ $0.003<0.01$ ) from the inventory, indicating that topic writing could help strengthen the critical thinking disposition of high school students in certain aspects. Increasing the themes of writing and prolonging the experiment period will probably be able to make student improve their critical thinking disposition more strongly. This ability training is suggested to be involved in school activities such as classroom teaching, homework, examination and extracurricular events, etc..

\section{Acknowledgement}

We thank the Bureau of Education in Hangzhou City of China (ZX13007004005) for the sponsorship to this research work.

\section{References}

[1] John, D. (Wenhe J. translated) (1991). How do we think? experience and education (pp. 45). Beijing: People's Education Press.

[2] Qin C. (2013). Preliminary study of cultivating students' critical thinking in high school biology teaching. Master degree thesis, Wuhan: Central China Normal University.

[3] National Research Council of United States. (1999). National Science Education Standards (pp. 123). Beijing: Science and Technology Press.

[4] Xiaohuan, Y. \& Dapeng Y. (2011). The students' critical thinking training in geography teaching under the new curriculum reform. New curriculum: Education academy, 4, 32-33. 
[5] The Ministry of Education of the People's Republic of China. (2003). High school biology curriculum standard. Beijing: People's Education Press.

[6] Meici, P., Guocheng, W., Jile, Ch., et al.. (2004). The reliability and validity test and research of Critical Thinking Disposition Inventory. Chinese Journal of Nursing, 9, 644-647.

[7] Shijian, W. (2014). Practical study of high school students' critical thinking disposition. The Journal of Shandong Normal University School of Foreign Languages: Elementary English teaching, 16, 24-29.

[8] Huiyun, G. (2009). The experimental study oncritical thinking training in biology teaching of high school. Master degree thesis, Kun Ming: Yunnan Normal University.

[9] Guangpu, Ouyang. (2012). The investigation on college students' critical thinking situation in China and the influencing factors - $\mathrm{H}$ University as an example. Master degree thesis, Wuhan: Huazhong University of Science and Technology.
[10] George, O. (Shaoming, L. translated). (2013). Nineteen eighty-four (pp. 235). Beijing: October Literature and Art Press.

[11] Xiaotong, F. (2013). Rural China (pp. 110). Beijing: SDX Joint Publishing Company.

[12] Boning, Zh. (2015). Investigating the correlation between inferiority feeling of middle school students and their family educationmethods. Research on Course Education, 30, 201-202.

[13] Guiqin, Zh. (2012). A preliminary study on diagnosis and treatment of avian influenza virus. China Abstract on Animal Husbandry and Veterinary, 7, 117.

[14] Xi, J. (2015). Cultivation of critical thinking in high school biology teaching - a case study of the current popular issues. Education Review: Mid-to-late issue, 12, 76-78. 